\title{
Conflict Resolution Revisited: \\ Peaceful Resolution, Mediation and Responsibility to Protect
}

\author{
Seán O Regan
}

\section{Introduction}

Alan Tidwell, the author of Conflict Resolved? A Critical Assessment of Conflict Resolution, ${ }^{1}$ wrote in the preface "Not all conflicts can or should be resolved; frankly there are some conflicts I do not wish to resolve - I want to win them." ${ }^{2}$ This is a real challenge to every person who aspires to be a peacemaker, and challenges, as Tidwell intended, the notion of peace at whatever cost. Tidwell argues that that while morally inspired positive peacemaking is a "good thing,"3 it can lack a sense of proportion, ignoring justice, right and wrong and deep-seated reasons for grievance. Similarly, evangelical theorists "propagate the value of conflict resolution at all costs" 4 and in the process lose a sense of reality about what can realistically be achieved. The increased adoption by states of early warning, conflict prevention and conflict resolution policies is often based on notions of positive peacemaking and inspired by evangelical theorists. Latterly mediation has been added to the arsenal of state-led conflict resolution tools.

This commentary will explore the limitations of mediation in relations between states, consider the implications for conflict resolution practice and advocate a principled international response to conflicts, including, if necessary, the need to win them.

\section{Principles of Peaceful Resolution}

The legal codification of the conduct of war, technological advances and the emergence of citizen armies through the nineteenth century all presumed that war is inevitable. The preambles of fin de siècle treaties ${ }^{5}$ on the conduct of war, where they exist, decry the evils of warfare but aim only to ameliorate rather than end those evils and their impacts on wounded combatants and civilians. While these could be devastating, in that era the overwhelming majority (95\%) of the casualties of war were the combatants. ${ }^{6}$ Even in the 1914-1918 war

Seán O Regan is an Irish diplomat currently serving in Slovenia. The views expressed in this essay are personal and should not be understood to represent or imply any of the policies or positions of the Government of Ireland. Email: seangtoregan@gmail.com.

Alan Tidwell, Conflict Resolved? A Critical Assessment of Conflict Resolution (London: Pinter, 1998).

Tidwell, Conflict Resolved? xi.

Tidwell, Conflict Resolved? xi

Tidwell, Conflict Resolved? xi.

For example, the Geneva Convention of 1906 begins as follows: "Being equally animated by the desire to lessen the inherent evils of warfare as far as is within their power, and wishing for this purpose to improve and supplement the provisions agreed upon at Geneva on 22 August 1864, for the amelioration of the condition of the wounded or sick in armies in the field." International Committee of the Red Cross, Convention for the Amelioration of the Condition of the Wounded and Sick in Armies in the Field. Geneva, 6 July 1906, accessed May 17, 2015, https://www.icrc.org/applic/ihl/ihl.nsf/Article.xsp?action=openDocument\&document $\mathrm{Id}=6 \mathrm{EA} 2 \mathrm{~B} 84 \mathrm{E} 6 \mathrm{E} 475670 \mathrm{C} 12563 \mathrm{CD} 00516215$

6 UNICEF, Impact of Armed Conflict on Children, accessed May 17, 2015, http://www.unicef.org/graca/patterns.htm. 
between the European great powers, civilian casualties were limited to $15 \%$, but by the end of the Second World War this had risen to $65 \%{ }^{7}$

The devastating impact of the 1914-1918 war led to the establishment of the League of Nations, whose purpose was stated in its founding Covenant as being

to promote international co-operation and to achieve international peace and security, by the acceptance of obligations not to resort to war, by the prescription of open, just and honourable relations between nations, by the firm establishment of the understandings of international law as the actual rule of conduct among Governments, and by the maintenance of justice and a scrupulous respect for all treaty obligations in the dealings of organised peoples with one another8.

The failure of the League of Nations to prevent the resumption of war in Europe spelled its end as an organisation, but the same principles were applied in the establishment of the United Nations in 1948. Its preamble opens as follows: "We the peoples of the United Nations determined to save succeeding generations from the scourge of war, which twice in our lifetime has brought untold sorrow to mankind," and goes on to enumerate principles of respect for human dignity and rights and the peaceful resolution of disputes between nations.

Regional organisations also committed themselves to peace. The origins of the EU lay in a determination that war should not occur in Europe again and aimed to achieve this through sharing the means of production and binding the nations of Europe together in their common interest. Until the early 1990s, the EU was still a small organisation of just 12 Member States, and had been extremely successful in ending the perennial conflicts between western European nation states. It had not until that point been especially engaged in conflict prevention beyond its borders and had largely confined itself to activity within the organisation itself.

Similarly, the Association of South East Asian States (ASEAN) in its Bangkok Declaration affirmed that it was established " $[\mathrm{t}] \mathrm{o}$ promote regional peace and stability through abiding respect for justice and the rule of law in the relationship among countries of the region and adherence to the principles of the United Nations Charter." Its 2007 Charter states that one of its purposes is " $[\mathrm{t}] \mathrm{o}$ maintain and enhance peace security and stability and further strengthen peace oriented values in the region." 10 The African Union, built on the Organisation for African Unity, states in its Constitutive Act that "the scourge of conflicts in Africa constitutes a major impediment to the socio-economic development of the continent" and says "the need to promote peace, security and stability" is "a prerequisite for the implementation of our development and integration agenda." It defines one of its objectives as to "promote peace, security, and stability on the continent." 11

Thus, there is a well-rehearsed commitment to the principle of peace and by implication the peaceful resolution of disputes. The bipolar world order established after the Second World War made a mockery of this commitment. The term conflict prevention in this era meant containing the potential for nuclear war between the major blocs. The ideological struggle between those blocs was carried into conflict all over the globe, notably in East Asia (Korea

\footnotetext{
7 UNICEF, Impact.

8 League of Nations, Covenant of the League of Nations, 1924, accessed May 18, 2015, http://avalon.law.yale.edu/20th century/leagcov.asp.

9 ASEAN, The Asean Declaration (Bangkok Declaration) Bangkok, 8 August 1967, accessed May 22, 2015, http://www. asean.org/news/item/the-asean-declaration-bangkok-declaration.

10 ASEAN, Charter of the Association of South East Asian Nations, November 20, 2007, accessed May 22, 2015, http://www. asean.org/asean/asean-charter/asean-charter.

11 African Union, Constitutive Act, July 11, 2000, accessed May 22, 2015, http://www.au.int/en/sites/default/files/Constitutive Act_en_0.htm.
} 
and Vietnam), Africa (the Congo and Angola) and Latin America (Chile and Nicaragua). The international community's response was generally to insert peacekeeping forces between parties in conflict without necessarily dealing with the root causes of the conflict. Many such conflicts ended with the collapse of the Soviet Union, but long-suppressed animosities between the constituent republics of that Union and its client states erupted. The international community's failure to deal with the ethnic/sectarian conflicts in the Caucasus and South Eastern Europe on the one hand and the Rwanda genocide on the other impelled discussion of conflict prevention from academia to foreign policy formation. While the UN and the OSCE had long-standing commitments to conflict prevention, exercise of all possible options was in practice limited by international politics. When it became clear that, as Smith ${ }^{12}$ put it, the balance of terror of the Cold War would not be replaced by peace and security, the issue of conflict prevention became prominent for the international community.

\section{Current Conflict Resolution Practice}

Van Waalraven ${ }^{13}$ explored the conflict policies of a sample of Western countries (Canada, the Netherlands, Norway, Sweden, and the United Kingdom) and found that general conflict policy, as against specific conflict intervention, was embedded in other, mainly development assistance, policies. He found it difficult to identify generic approaches to conflict prevention, although all countries examined used similar language in their descriptions of conflict and its causes, even if there was only vague consensus on what those causes are.

The Council of the European Union, at its June 2001 meeting in Gothenburg, ${ }^{14}$ endorsed a programme of conflict prevention, ${ }^{15}$ stating this would "improve the Union's capacity to undertake coherent early warning, analysis and action [to prevent conflict]" and that "[c] onflict prevention is one of the main objectives of the Union's external relations and should be integrated in all its relevant aspects." This document and the European Security Strategy ${ }^{16}$ provided the foundation for the elaboration of a whole series of policies, including the promotion of mediation in conflict prevention and resolution. It was followed in 2009 by the "Concept on Strengthening EU Mediation and Dialogue Capacities," ${ }^{17}$ which uses the term mediation to encompass improved communication, negotiation, dialogue and facilitation through the offices of a third party, namely the EU. In this document mediation can be directive and coercive. It also notes the EU's financial power and moral authority as positive factors in a mediation process.

A number of individual countries have claimed particular attachment to conflict prevention and resolution as a fundamental part of their foreign policy. Finland promotes mediation as a core tool to resolve all phases of the conflict cycle, and with Turkey, initiated a Friends of Mediation group at the United Nations in 2010. In addition, in 2011 it published a national action plan to support mediation in conflict prevention. ${ }^{18}$ For its part, Turkey asserts that each

\footnotetext{
12 Karen Smith, European Union Foreign Policy in a Changing World (Cambridge: Polity Press, 2008).

13 Klaas Van Walraven, Conflict Policy in some Western Countries (The Hague: Netherlands Institute of International Studies, Clingendael, 1999).

14 EU Council, Council Conclusions SN 200/1/01 Rev 1, Goteberg: European Union, June 16, 2001.

15 European Commission, Draft European Union Programme for the Prevention of Violent Conflicts 9537/ 01/ 1 Rev 1, Brussels, June 7, 2001.

16 EU Council, A Secure Europe in a Better World, December 12, 2003, accessed May 18, 2015, https://www.consilium.europa. eu/uedocs/cmsUpload/78367.pdf .

17 European Commission, Concept on Strengthening EU Mediation and Dialogue Capacities 15779/09, Brussels: EU, November 10, 2009.

${ }_{18}$ Ministry for Foreign Affairs of Finland, Mediation, April 23, 2014, accessed May 17, 2015, http://formin.finland.fi/public/
} 
conflict "has its own dynamics and conditions; and that mediation efforts should be carried out with a view to safeguard differences and in a manner which is flexible and free from uniformity." 19 Turkey outlines certain principles that it claims are required of a mediator, including extensive expert knowledge, the capacity to propose flexible but value-based strategies, the ability to earn the confidence of the parties and a commitment to confidentiality. Together with Finland and Switzerland, Turkey established a "Friends of Mediation Group" within the OSCE in March 2014. ${ }^{20}$ Switzerland has an extensive and long-standing commitment to conflict resolution. Its wide range of activity includes the advancement of power sharing, democratic reform (including control of security forces and election management, human rights and humanitarian international law, reconciliation processes, mutual ideological understanding and disarmament (especially land mines and small arms)). Switzerland claims that since the end of the Cold War almost all conflicts have been resolved through the good offices of a third party, and distinguishes in this between facilitation (a more neutral, less directive and almost external role) and mediation (which it sees as requiring a mandate from the parties to the conflict and the mediator playing an active role in finding a solution for the parties. ${ }^{21}$ While Norway has not published a conflict resolution policy, it is widely regarded as a leading proponent of conflict resolution. In a speech in Ankara in 2013, ${ }^{22}$ Norway's Foreign Minister outlined that country's approach to conflict resolution. He noted that while each process is different, they do have commonalities, and outlined four basic principles: dialogue is crucial; peace processes take time; inclusiveness is key and experience of other peace processes is helpful. Embedded in the Norwegian approach are commitments to strengthening international law, human rights (including fundamental freedoms), gender equality, social justice and economic development. Although not explicitly stated, there is also recognition of the importance of mediation.

The above is a small sample of the conflict resolution efforts of many countries, but what is interesting about this grouping, which ostensibly works together to promote conflict resolution, is the diversity of approach. Norway uniquely contemplates that military force may be necessary in the resolution of conflicts (although qualifies this by saying force is not sufficient of itself). Only Finland has a national action plan to promote mediation. Switzerland relies on government-funded NGOs to advance its international efforts and Turkey uses its own state instruments. There are differences in the emphasis on the reasons for promoting conflict resolution as part of state policy, ranging from state security, through regional influence and economic well-being, to human rights and justice. These differences may well be regarded as the sort of variation in style that is widely discussed in the literature but they are beyond the scope of this essay. However, there is also a body of literature that examines why states mediate, and some of the reasons for variation may be found there.

Zartmann and Touval ${ }^{23}$ found that states seek to resolve conflict out of self-interest. This may be defensive, aimed at increasing security (globally or regionally); or protecting

\footnotetext{
default.aspx? contentid=259341\&contentlan=2\&culture=en-US\#National measures to promote mediation.

19 Ministry of Foreign Affairs of Turkey, Resolution of Conflicts and Mediation, accessed May 17, 2015, http://www.mfa.gov. tr/resolution-of-conflicts-and-mediation.en.mfa.

20 Ministry of Foreign Affairs of Turkey, Conflicts and Mediation.

21 Switzerland Federal Department of Foreign Affairs, Peace, Fabruary 20, 2015, accessed May 17, 2015, https://www.eda admin.ch/eda/en/fdfa/foreign-policy/human-rights/peace.html.

${ }^{22}$ Børge Brende, "International Mediation Trends: Processes and Experiences" (opening speech at the Seminar on Turkish and Norwegian Approaches to Mediation, Ankara, Turkey, November 6, 2013.

${ }_{23}$ I. William Zartmann and Saaid Touval, "International Mediation in the Post-Cold War Era," in Managing Global Chaos, ed. Chester Crocker, Fen Hampson and Pamela Aall, 445-61 (Wasington DC: United States Institute of Peace, 1996).
} 
external interests or blocking another state from becoming involved in the conflict resolution process; or offensive, aimed at increasing influence or reputation. Smaller states may engage in mediation because they lack other tools to achieve defensive or offensive foreign policy objectives. Zartmann and Touval interestingly note that states in conflict only engage in mediation if continued conflict or failure to engage with the mediator will result in greater harm to themselves, or if it might provide future advantage. The mediation process is therefore engaged with also out of self-interest. In short, positive peace is seldom the motivation for state engagement in mediation.

Melin $^{24}$ confirmed this finding with an elegant demonstration that the number of state-led mediation processes increased in line with the number of conflicts and is not dependent on any presumed finite number of mediators. She argued that states will act as mediators only if to do so "enhances their influence, resources and power." She also cited evidence that states are more likely to mediate if they have political or economic ties to one or both of the disputing parties; that is, they are unlikely to be neutral. Melin went on to describe seven factors that increase the likelihood that mediation to resolve conflict will occur: democracy (democratic states are more ready to mediate, as mediators and disputants); capability (which affects willingness to mediate, acceptance by the parties and success of outcome); cost of conflict (opportunity cost of not resolving conflict); impasse or stalemate in conflict; secular rivalry or reoccurring conflict; the conflict is inter-statal not intra-statal and a history of previous mediation.

\section{The Limitations of Mediation}

Bercovitch defines mediation as

a process of conflict management, related to but distinct from the parties' own negotiations, where those in conflict seek the assistance of, or accept an offer of help from, an outsider (whether an individual, an organization, a group, or a state) to change their perceptions or behaviour, and do so without resorting to physical force or invoking the authority of law. ${ }^{25}$

Much of Bercovitch's work focussed on distilling best practice from empirical studies. His analysis is based on long-term samples in multiple regions and the establishment of robust data sets, which allowed him to offer more objective measures of policy success and failure than individual case studies might. Although his study was not limited to the mediation efforts of state actors, Bercovitch found that $75 \%$ of attempts to mediate international conflicts between 1945 and 2000 failed at least partially. By his count, 272 of the 333 conflicts in the period were subject to some form of external intervention, and of those 192 were mediations, some of which comprised multiple mediation efforts. The outcomes include reduction, not end, to violence in $27 \%$ of cases and outright failure in $57 \%$ of cases. ${ }^{26}$

Perhaps the most mediated conflict of the past seven decades is that between the State of Israel and its Arab neighbours. Given the multiplicity of efforts by states, NGOs and prominent individuals, it is difficult to establish precisely how many mediation attempts have been made to resolve the conflict. The vast majority has failed. Siniver ${ }^{27}$ counts five that

\footnotetext{
${ }^{24}$ Molly Melin, "When States Mediate," Penn State Journal of Law and International Affairs 2, no. 1 (April 2013).

${ }_{25}$ Jacob Bercovitch, "Mediation in International Conflict: An Overview of Theory, A Review of Practice," in Peacemaking in International Conflict: Methods and Techniques, ed. I. William Zartman and J. Lewis Rasmussen (Washington DC: United States Institute for Peace, 1997), 130.

${ }^{26}$ Daniel Druckman and Carmela Lutmar, "Jacob Bercovitch: Understanding Hands across the Divide," Negotiation and Conflict Management Research 5, no. 4 (2012): 325-30.

${ }_{27}$ Asaf Siniver, "Power, Impartiality and Timing: Three Hypotheses on Third Party Mediation in the Middle East," Political
} 
have had any success: the 1949 agreements defining the Green Line; US Secretary of State Kissinger's two interventions after the Yom Kippur War in 1973; President Carter's Camp David mediation leading to the Israel-Egypt peace treaty of 1979 and the Oslo process, the principles of which endure despite the failures in implementation. In each of these cases, there were elements of coercion by the mediator, there was a power balance between the disputants and the mediator had a high status and was perceived to be partial. Although historically much of the focus in the Middle East has been on the mediation of the IsraeliArab conflict, there are multiple other conflicts in the region, many of which have also been subject to failed mediation (for example, the mission of Lakhdar Brahimi in Syria ${ }^{28}$ and international efforts in Egypt $^{29}$ ).

Similar patterns of the failure of mediation were repeated in Somalia, ${ }^{30}$ Sri Lanka, ${ }^{31}$ Congo and $\operatorname{Sudan}^{32}$ and in other conflicts. It is beyond the scope of this essay to examine why these failures occur with such frequency but Lakhdar Brahimi lists the deadly sins of mediation as ignorance, arrogance, partiality, impotence, haste, inflexibility and false promises. ${ }^{33}$ In the international context one has to add also geopolitical realities. This is well demonstrated in the case of Sri Lanka, where the principal mediator identified geopolitical rivalry between India and China as a major factor in the collapse of its mediation efforts. ${ }^{34}$

\section{Responsibility to Protect, Legitimate Intervention and Armed Force}

Against this background of the general failure of mediation, and bearing in mind Tidwell's concerns about reality, proportionality, justice, ethics and grievance, one has to ask if there is a better way for the international community to resolve disputes between and within states, including taking sides and winning them.

Although there are a wide variety of traditions surrounding the propriety of using violence to assert or restore justice, in the Western world it is St. Augustine of Hippo who is usually described as the originator of Just War doctrine. St. Thomas Aquinas elaborated the doctrine within the Roman Catholic tradition, putting lawful authority, just cause and right intention at its centre. He was followed by several others, including de Vittoria, in the development of an elaborate tradition of tests to be passed to ensure that a war was entered into justly (jus ad bello), conducted justly (jus in bello) and exited justly (jus post bello). The tradition evolved in parallel with the evolution of the Westphalian model of sovereign states and ultimately became defined in the context of war between states. This broad tradition has been brought back to public consciousness by the scholar Michael Walzer, largely because of his principled and vocal opposition to certain military actions, notably the 2003 US-led invasion of Iraq,

Studies 54, no. 4 (2006): 806-26

28 Ian Black, "UN Syria envoy Lakhdar Brahimi resigns after failure of Geneva talks, ” The Guardian, May 13, 2014, accessed May 23, 2015, http://www.theguardian.com/world/2014/may/13/un-syria-envoy-lakhdar-brahimi-resigns.

29 "Egypt says foreign mediation has failed to resolve crisis," BBC, August 7, 2013, accessed May 23, 2015, http://www.bbc. com/news/world-middle-east-23601349.

30 Ken Menkhaus, "Mediation Efforts Somalia," AFRICA Mediators' Retreat 2007 - The Oslo forum Network of Mediators, accessed May 23, 2015, http://www.osloforum.org/sites/default/files/MediationEffortsSomaliaKenMenkhaus.pdf.

31 J. Jeganaathan, "Norway in Sri Lanka: A Tale of the Failed Peace Process," Institute of Peace and Conflict Studies, November 30, 2011, accessed May 23, 201, http://www.ipcs.org/article/terrorism/norway-in-sri-lanka-a-tale-of-the-failed-peace-3502.html.

32 Laurie Nathan, "The Challenges Facing Mediation in Africa," AFRICA Mediators' Retreat 2009 - The Oslo forum Network of Mediators, accessed May 23, 2015, https://www.osloforum.org/sites/default/files/The $\% 20$ challenges $\% 20$ facing $\% 20$ mediation\%20in\%20Africa.pdf.

33 Lakhdar Brahimi and Salman Ahmed, In Pursuit of Sustainable Peace: The Seven Deadly Sins of Mediation (New York: Centre on International Cooperation, 2008).

34 NORAD, Pawns of Peace: Evaluation of Norwegian peace efforts in Sri Lanka 1997-2009. (Oslo: NORAD, 2011). 
and his justification of others. His recognition of the changed nature of modern war, as being often between state and non-state actors and the application of the Just War tradition is especially important. Also of great importance has been Walzer's examination of who is now the "lawful authority" required under the Thomist definition of "just war." He has largely, but not uncontroversially, exempted US citizens from responsibility for the Iraq war on the grounds that they were excluded from the decision making process and deliberately isolated from its effects by the US administration. Thus, their proper role as the lawful authority was removed. ${ }^{35}$ Walzer's greatest contribution, however, may be his reminder to the international community that, in certain circumstances, war, in some form, might be a moral imperative. This would clearly be the case in respect of gross violations of international humanitarian law of the type seen in Cambodia under the Khmer Rouge and in Rwanda during the genocide of 1994. However, it was often less clear in the Balkans in the 1990s.

It was largely in response to such events that the Government of Canada announced in September 2000 the establishment of the International Commission on Intervention and State Sovereignty (ICISS). The Commission built on Francis Deng's seminal work Sovereignty as Responsibility ${ }^{36}$ to produce a report entitled The Responsibility to Protect. ${ }^{37}$ Deng had argued that sovereignty could not be regarded as a guarantee of non-interference but rather had to be thought of as a responsibility to citizens and the wider international community to ensure good governance, which in turn implied political stability, economic development and social justice. The ICISS set out a new framework for the concept of sovereignty and insisted that it was not declaring a right to intervene but rather a responsibility to protect. Within that framework it set out a need to redefine security to include the idea of human security, recognising that there was already in place an international legal framework (including the Universal Declaration of Human Rights, the International Covenant on Civil and Political rights, the Covenant on Economic and Social Rights, the Genocide Convention, the Geneva Conventions and additional protocols, the Rome Statue of the International Criminal Court) and an emerging practice at the UN Security Council and in regional organisations to recognise internal political instability and violence as a threat to international peace. In order to exercise the responsibility to protect, the ICISS suggested that there were additional responsibilities, namely to prevent (conflict), to react (when conflict breaks out) and to rebuild (when conflict ends). The timing of the publication of the report in December 2001, shortly after the attack on the World Trade Centre in New York was not auspicious. Nor was the cause of the Responsibility to Protect concept assisted by its conflation with humanitarian intervention, a narrower concept, and the assertion that the US-led invasion of Iraq in 2003 was for humanitarian purposes. However, then UN Secretary General Kofi Annan persisted and the High-level Panel on Threats, Challenges and Change (HLP), which he constituted, set out a new set of principles for the better application of existing international law. ${ }^{38}$ The HLP asserted that

the Charter of the United Nations, properly understood and applied, is equal to the task [of maintaining peace and security]: Article 51 needs neither extension nor restriction of its long-

\footnotetext{
${ }^{35}$ Garry Wills, "What is a Just War?" New York Review of Books, November 18, 2004.

${ }^{36}$ Francis Deng, Sovereignty as Responsibility (Washington DC: Brookings Institute, 1996).

${ }^{37}$ International Commission on Intervention and State Sovereignty. The Responsibility to Protect (Ottawa: International Developemnt Research Centre, 2001).

${ }^{38}$ High-level Panel on Threats, Challenges and Change, A More Secure World: Our Shared Responsibility (New York: United Nations, 2004).
} 
understood scope, and Chapter VII fully empowers the Security Council to deal with every kind of threat that States may confront. The task is not to find alternatives to the Security Council as a source of authority but to make it work better than it has..$^{39}$

The HLP embedded the international responsibility to protect in its report and offered five criteria that should be met to legitimate military intervention (which remarkably echo traditional just-war principles): seriousness of threat, proper purpose, last resort, proportional means and balance of consequences. The HLP report was part of a wider UN reform agenda, and while there was broad agreement about the principles set out in the report and Kofi Annan's own response ${ }^{40}$ to it, reform has progressed at a glacial pace.

Scepticism about responsibility to protect, expressed as a belief that it is nothing more than a front for neo-colonialism, neo-imperialism and regime change, is widespread, as any Internet search will reveal. The continued instability in Libya and Tunisia and the ongoing conflict in Syria are also cited by those opposed to responsibility to protect. These criticisms generally fail to distinguish between military intervention cloaked in humanitarian justification and real responsibility to protect, which includes not only a military phase, but also prevention and rebuilding phases.

Despite these challenges, Responsibility to Protect is still strongly advocated by the NGO community and by many states and in the academic world. The current Secretary General of the UN has said that he will spare no effort to operationalise responsibility to protect ${ }^{41}$ and associated concepts like human security, peacebuilding and stabilisation have been mainstreamed. The US military doctrine has evolved to include humanitarian protection and the EU has developed an impressive array of civilian crisis management tools which depend on the Responsibility to Protect concept.

As Responsibility to Protect evolves, it separates itself further from the concept of humanitarian intervention, as envisaged in the ICISS report. It becomes less about the legal right to intervene and more about the moral obligation to do so. What still remains difficult is the definition of who exercises the responsibility to protect. Welsh said that if everyone is responsible nobody is responsible ${ }^{42}$ but acknowledges there is no clear answer. Several regional organisations and large states have taken the responsibility unto themselves but this has raised questions of legality and legitimacy and the UN itself continues to assert that sovereignty, in the Westphalian sense, cannot be breached. ${ }^{43}$

\section{Conclusions}

The international community has for generations sought to achieve peace within and between states. It has moved from a treaty-based enforcement of rules of war to a broad consensus that peace is preferable. However, it has not determined a way to prevent all conflict and the attachment to peaceful resolution of disputes through negotiation and mediation has not been

${ }^{39}$ High-level Panel, A More Secure World, 143

${ }^{40}$ Kofi Annan, In Larger Freedom (New York: United Nations, 2005).

${ }^{41}$ Mary Kaldor, "A Decade of the 'War on Terror' and the 'Responsibility to Protect': the Global Debate about Military Intervention," 10 Years after September 11, accessed May 24, 2015, http://essays.ssrc.org/10yearsafter911/a-decade-of-the$\% \mathrm{E} 2 \% 80 \% 9 \mathrm{C}$ war-on-terror $\% \mathrm{E} 2 \% 80 \% 9 \mathrm{D}$-and-the- $\% \mathrm{E} 2 \% 80 \% 9$ Cresponsibility-to-protect $\% \mathrm{E} 2 \% 80 \% 9 \mathrm{D}$-the-global-debateabout-military-intervention-2/.

${ }^{42}$ Cited in Jennifer Welsh, interview by Alex Leveringhaus, "Interventionism, the 'Responsibility to Protect' and the Interaction between Academics and Policymakers," University of Oxford, 2014, accessed May 31, 2015, http://www.politics.ox.ac. $\mathrm{uk} / \mathrm{ke}$-feature/interventionism-the-responsibility-to-protect-and-the-interaction-between-academics-and-policymakers.html.

${ }^{43}$ Jayshree Bajoria and Robert McMahon, "The Dilemma of Humanitarian Intervention," Council on Foreign Relations, accessed May 31, 2015, http://www.cfr.org/humanitarian-intervention/dilemma-humanitarian-intervention/p16524. 
successful. Indeed, periods of negotiation and mediation have been used by parties to conflict to re-arm and re-establish in preparation for the resumption of hostilities. If the international community is truly interested in ensuring peace and stability, it has an obligation to mitigate the reasons for conflict, anticipate conflict and where possible prevent it. Where that fails it must also be prepared, having applied the criteria of seriousness of threat, proper purpose, last resort, proportional means and balance of consequences, to intervene with military force to stop conflict, including through the removal of the conflict instigators. In itself this is not sufficient, however, because the international community must not forget that it also has an obligation to rebuild a society in which peace has broken down, and this must include a full programme of societal transformation to address historical grievance, economic inequality and political disempowerment which are at the heart of almost all conflicts.

\section{Bibliography}

African Union. Constitutive Act. July 11, 2000. Accessed May 22, 2015. http:/www.au.int/en/sites/default/files/ Constitutive_Act_en_0.htm.

Annan, Kofi. In Larger Freedom. New York: United Nations, 2005.

ASEAN. The Asean Declaration (Bangkok Declaration) Bangkok, 8 August 1967. Accessed May 22, 2015. http:// www.asean.org/news/item/the-asean-declaration-bangkok-declaration.

ASEAN. Charter of the Association of South East Asian Nations. November 20, 2007. Accessed May 22, 2015. http://www.asean.org/asean/asean-charter/asean-charter.

Bajoria, Jayshree, and Robert McMahon. "The Dilemma of Humanitarian Intervention.” Council on Foreign Relations. Accessed May 31, 2015. http://www.cfr.org/humanitarian-intervention/dilemma-humanitarianintervention/p16524.

Bercovitch, Jacob. "Mediation in International Conflict: An Overview of Theory, A Review of Practice." In Peacemaking in International Conflict: Methods and Techniques, edited by I. William Zartman and J. Lewis Rasmussen, 125-54. Washington DC: United States Institute for Peace, 1997.

Black, Ian. "UN Syria envoy Lakhdar Brahimi Resigns after Failure of Geneva talks.” The Guardian, May 13, 2014. Accessed May 23, 2015. http://www.theguardian.com/world/2014/may/13/un-syria-envoy-lakhdar-brahimiresigns.

Brahimi, Lakhdar, and Salman Ahmed. In Pursuit of Sustainable Peace: The Seven Deadfly Sins of Mediation. New York: Centre on International Cooperation, 2008.

Brende, Børge. "International Mediation Trends: Processes and Experiences." Opening speech at the Seminar on Turkish and Norwegian Approaches to Mediation, Ankara, November 6, 2013.

Deng, Francis. Sovereignty as Responsibility. Washington DC: Brookings Institute, 1996.

Druckman, Daniel, and Carmela Lutmar. "Jacob Bercovitch: Understanding Hands across the Divide." Negotiation and Conflict Management Research 5, no. 4 (2012): 325-30.

EU Council. A Secure Europe in a Better World. Brussels, December 12, 2003. Accessed May 18, 2015. https:// www.consilium.europa.eu/uedocs/cmsUpload/78367.pdf.

EU Council. Council Conclusions SN 200/1/01 Rev 1. Goteberg: European Union, June 16, 2001.

European Commission. Concept on Strengthening EU Mediation and Dialogue Capacities 15779/09. Brussels, November 10, 2009.

European Commission. Draft European Union Programme for the Prevention of Violent Conflicts 9537/ 01/ 1 Rev 1. Brussels, June 7, 2001.

High-level Panel on Threats, Challenges and Change. A More Secure World: Our Shared Responsibility. New York: United Nations, 2004.

International Committee of the Red Cross. Convention for the Amelioration of the Condition of the Wounded and 
Sick in Armies in the Field. Geneva, 6 July 1906. Accessed May 17, 2015 https://www.icrc.org/applic/ihl/ihl.nsf/ Article.xsp?action=openDocument\&documentId=6EA2B84E6E475670C12563CD00516215.

International Commission on Intervention and State Sovereignty. The Responsiobility to Protect. Ottawa: International Developemnt Research Centre, 2001.

Jeganaathan, J. "Norway in Sri Lanka: A Tale of the Failed Peace Process." Institute of Peace and Conflict Studies. November 30, 2011. Accessed May 23, 2015. http://www.ipcs.org/article/terrorism/norway-in-sri-lanka-a-taleof-the-failed-peace-3502.html.

Kaldor, Mary. "A Decade Of The "War On Terror" And The "Responsibility To Protect": The Global Debate About Military Intervention." 10 Years after September 11. 2011. Accessed May 24, 2015. http:// essays.ssrc.org/10yearsafter911/a-decade-of-the- $\% \mathrm{E} 2 \% 80 \% 9 \mathrm{Cwar}$-on-terror $\% \mathrm{E} 2 \% 80 \% 9 \mathrm{D}$-and-the$\% \mathrm{E} 2 \% 80 \% 9$ Cresponsibility-to-protect $\% \mathrm{E} 2 \% 80 \% 9 \mathrm{D}$-the-global-debate-about-military-intervention- $2 /$.

League of Nations. Covenant of the League of Nations.1924. Accessed May 18, 2015. http://avalon.law.yale. edu/20th_century/leagcov.asp.

Melin, Molly. "When States Mediate." Penn State Journal of Law and International Affairs 2, no. 1 (April 2013): 78-90.

Menkhaus, Ken. "Mediation Efforts Somalia.” AFRICA Mediators' Retreat 2007 - The Oslo forum Network of Mediators. Accessed May 23, 2015. http://www.osloforum.org/sites/default/files/MediationEffortsSomaliaKen Menkhaus.pdf.

Ministry of Foreign Affairs of Turkey. Resolution of Conflicts and Mediation. Accessed May 17, 2015. http://www. mfa.gov.tr/resolution-of-conflicts-and-mediation.en.mfa.

Ministry for Foreign Affairs of Finland. Mediation. April 23, 2014. Accessed May 17, 2015. http://formin.finland. fi/public/default.aspx?contentid=259341\&nodeid=49301\&contentlan=2\&culture=en-US\#National_measures to_promote_mediation.

Nathan, Laurie. "The Challenges Facing Mediation in Africa." AFRICA Mediators' Retreat 2009 - The Oslo forum Network of Mediators. Accessed May 23, 2015. https://www.osloforum.org/sites/default/files/The\%20 challenges $\% 20$ facing $\% 20$ mediation $\% 20$ in $\% 20$ Africa.pdf.

NORAD. Pawns of Peace: Evaluation of Norwegian peace efforts in Sri Lanka 1997-2009. Oslo: NORAD, 2011.

Siniver, Asaf. "Power, Impartiality and Timing: Three Hypotheses on Third Party Mediation in the Middle East." Political Studies 54, no. 4 (2006): 806-26.

Smith, Karen. European Union Foreign Policy in a Changing World. Cambridge: Polity Press, 2008.

Switzerland Federal Department of Foreign Affairs. Peace. February 20, 2015. Accessed May 17, 2015. https:// www.eda.admin.ch/eda/en/fdfa/foreign-policy/human-rights/peace.html.

Tidwell, Alan. Conflict Resolved? A Critical Assessment of Conflict Resolution. London: Pinter, 1998.

UNICEF. Impact of Armed Conflict on Children. Accessed May 17, 2015. http://www.unicef.org/graca/patterns.htm.

Van Walraven, Klaas. Conflict Policy in some Western Countries. The Hague: Netherlands Institute of International Studies, Clingendael, 1999.

Welsh, Jennifer. "Interventionism, the 'Responsibility to Protect' and the Interaction between Academics and Policymakers.” By Alex Leveringhaus. University of Oxford, 2014. Accessed May 31, 2015. http://www.politics. ox.ac.uk/ke-feature/interventionism-the-responsibility-to-protect-and-the-interaction-between-academics-andpolicymakers.html.

Wills, Garry. "What is a Just War?" New York Review of Books, November 18, 2004.

Zartmann, I. William, and Saaid Touval. "International Mediation in the Post-Cold War Era." In Managing Global Chaos, edited by Chester Crocker, Fen Hampson and Pamela Aall, 445-61. Wasington DC: United States Institute of Peace, 1996. 